\title{
Penetration Behavior of Calcium Ferrite Melts into Hematite Substrate
}

\author{
Shinji YOSHIMURA, ${ }^{1)}$ Keiko KUROSAWA, ${ }^{2)}$ Yoshiaki GONDA, ${ }^{2)}$ Sohei SUKENAGA, ${ }^{3)}$ Noritaka SAITO ${ }^{3)}$ and \\ Kunihiko NAKASHIMA ${ }^{3)}$
}

1) Formerly at Graduate Student of Kyushu University, now at Aichi Steel Corp., 744 Motooka Nishi-ku, Fukuoka $819-0395$ Japan. $\quad$ 2) Graduate Student, Kyushu University, 744 Motooka Nishi-ku, Fukuoka 819-0395 Japan.

3) Department of Materials Science and Engineering, Graduate School of Engineering, Kyushu University, 744 Motooka Nishiku, Fukuoka 819-0395, Japan.

(Received on October 2, 2008; accepted on January 20, 2009)

\begin{abstract}
Effects of adding $\mathrm{SiO}_{2}$ or $\mathrm{Al}_{2} \mathrm{O}_{3}$ on the penetration characteristics of calcium ferrite (CF) melts into hematite substrate with the different percentage of porosity were examined, and were discussed from the viewpoints of the relation to the solubility gap, $\Delta \mathrm{Fe}_{2} \mathrm{O}_{3}(\mathrm{~mol} \%)$, viscosity and surface tension of the CFbased melts.

In case of dense hematite substrate with $5 \%$ porosity, the penetration depth of CF melts into hematite substrate was depressed by the addition of $\mathrm{SiO}_{2}$ or $\mathrm{Al}_{2} \mathrm{O}_{3}$, and the addition of $\mathrm{SiO}_{2}$ was more effective than that of $\mathrm{Al}_{2} \mathrm{O}_{3}$. Moreover, the penetration of $\mathrm{CF}$-based melts along grain boundaries into hematite substrate did not take place, and melts/hematite interface moved down by dissolution of solid hematite into these melts. The penetration depth of CF-based melts into hematite substrate was mostly determined by $\Delta \mathrm{Fe}_{2} \mathrm{O}_{3}$ (mol\%), which meant that the dissolution of hematite into melts was rate-determine.

In case of porous hematite substrate with $15 \%$ porosity, the penetration of CF-based melts along grain boundaries into hematite substrate occurred, and the penetration depth was 10 times deeper than the case of dense hematite substrate with $5 \%$ porosity for each slag. The penetration depth of CF melts was increased by the addition of $\mathrm{SiO}_{2}$ due to the decrease of melting temperature in the calcium ferrite system. The penetration depth of CF melts with the addition of $\mathrm{Al}_{2} \mathrm{O}_{3}$ was very similar to that of CF melts. These melts penetrated into hematite substrate with crystallization (solid) due to the increase of the melting temperature in calcium ferrite system by the dissolution of hematite into the liquid phase. The penetration depth of CF-based melts into hematite substrate was dominated by the ratio between the surface tension and viscosity of melts taking the suspension-corrected into consideration.
\end{abstract}

KEY WORDS: calcium ferrite melts; hematite substrate; porosity; penetration behavior.

\section{Introduction}

In the current blast furnace process, the amount of iron ore sinter has been increased because of maintaining the stable operations and increasing its productivity. ${ }^{1,2)}$ The iron ore sinter is produced by liquid phase sintering, the formation and the flow of melts play important role to assist the agglomeration in the sintering process of fine ores for controlling the strength and the reducibility of iron ore sinter. ${ }^{3)}$ It is reported that the composition of the melts starts from that of mono-calcium ferrite $\left(\mathrm{CaO} \cdot \mathrm{Fe}_{2} \mathrm{O}_{3}\right)$, meaning the lowest temperature that the $\mathrm{CaO}-\mathrm{Fe}_{2} \mathrm{O}_{3}$ system evolves melt. ${ }^{4,5)}$ Recently, as the usage of limonite ore has been increased, ${ }^{6,7)}$ so that it is important to determine the effects of ore porosity and gangue, such as $\mathrm{SiO}_{2}$ or $\mathrm{Al}_{2} \mathrm{O}_{3}$, on the behavior of melts formation and flow during the iron ore sintering, and also important to decrease the sintering temperature by the formation of melts with low melting temperature. ${ }^{8,9)}$

In this study, the effects of ore porosity and melts com- position (adding $\mathrm{SiO}_{2}$ or $\mathrm{Al}_{2} \mathrm{O}_{3}$ ) on the penetration behavior of melts into iron ore have been examined, and discussed with the relation to solubility gap of $\mathrm{Fe}_{2} \mathrm{O}_{3}$, viscosity and surface tension of the melts.

\section{Samples and Experimental Procedures}

We allowed the reaction couple to simulate melts-ore system for sintering reaction, which composed melts former on a hematite substrate as shown in Fig. 1(a). The chemical compositions of the melts former used in these experiments are listed in Table 1. The melts former, $\mathrm{CF}$ $\left(\mathrm{CaO} \cdot \mathrm{Fe}_{2} \mathrm{O}_{3}\right)$, CF with $\mathrm{Al}_{2} \mathrm{O}_{3}(\mathrm{CF}-3 \mathrm{~A}$ and $\mathrm{CF}-5 \mathrm{~A})$ and $\mathrm{SiO}_{2}(\mathrm{CF}-3 \mathrm{~S}$ and CF-5S) at different content of additive, 3 and 5 mass $\%$, respectively, were synthesized by premelting a mixture of chemical reagents at desired ratios. The slag powders (under $44 \mu \mathrm{m}$ ) were shaped into tablet $(\phi 7 \mathrm{~mm} \times 2.0 \mathrm{~mm})$ and examined.

The hematite substrate $(\phi 24 \mathrm{~mm} \times 8 \mathrm{~mm})$ changed in porosity for representing dense ores or porous ones. The 


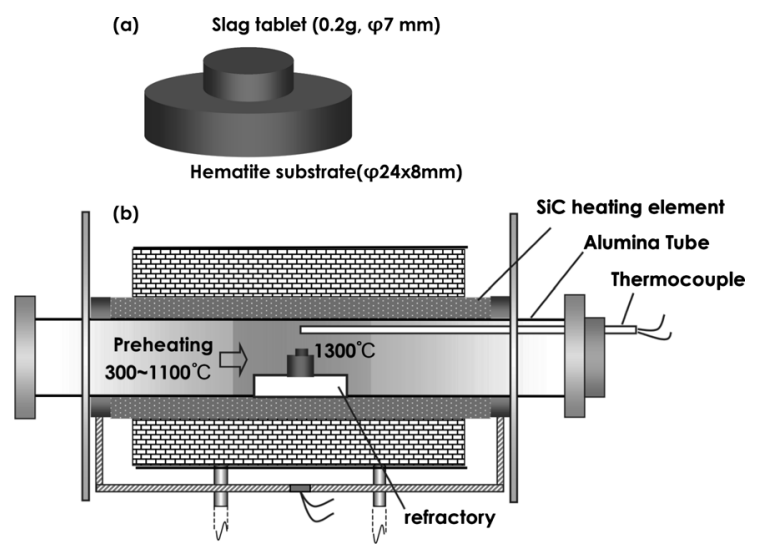

Fig. 1. Schematic drawing of sample configuration (a) and apparatus (b) for experiment.

Table 1. Chemical composition of melts former (mass\%).

\begin{tabular}{c|c|c|c|c}
\hline & $\mathrm{CaO}$ & $\mathrm{Fe}_{2} \mathrm{O}_{3}$ & $\mathrm{Al}_{2} \mathrm{O}_{3}$ & $\mathrm{SiO}_{2}$ \\
\hline $\mathrm{CF}$ & 26.0 & 74.0 & - & - \\
\hline $\mathrm{CF}-3 \mathrm{~A}$ & 25.2 & 71.8 & 3.0 & - \\
\hline $\mathrm{CF}-5 \mathrm{~A}$ & 24.7 & 70.3 & 5.0 & - \\
\hline $\mathrm{CF}-3 \mathrm{~S}$ & 25.2 & 71.8 & - & 3.0 \\
\hline $\mathrm{CF}-5 \mathrm{~S}$ & 24.7 & 70.3 & - & 5.0 \\
\hline
\end{tabular}

dense substrate was prepared by pressing hematite powder reagent (under $10 \mu \mathrm{m}$ ), and then sintered them at $1300^{\circ} \mathrm{C}$ for $3 \mathrm{~h}$ to give $5 \%$ porosity. The porous one was prepared by pressing hematite powder reagent (under $10 \mu \mathrm{m}$ ) with $4 \mathrm{wt} \%$ wheat powder, and sintered them at $1300^{\circ} \mathrm{C}$ for $30 \mathrm{~min}$ after pre-sintering at $500^{\circ} \mathrm{C}$ for $30 \mathrm{~min}$ to give $15 \%$ porosity.

The sample configuration (a) and the experimental apparatus (b) used in this study are schematically shown in Fig. 1. A slag former tablet was placed on a hematite substrate, and put it in the furnace. After preheating at the temperature zone from $300-1000^{\circ} \mathrm{C}$ for $30 \mathrm{~min}$, the sample was inserted into the temperature region at $1300^{\circ} \mathrm{C}$, for different periods, 3,5 or $10 \mathrm{~min}$, then extracted from the furnace and cooled in air. The sample of the hematite substrate with solidified droplets were dissected perpendicular to the interface, and polished with $1 \mu \mathrm{m}$ diamond paste. The cross sections of these samples were examined using an optical microscope, a scanning electron microscopy (SEM) and an electron probe micro analyzer (EPMA).

\section{Results and Discussion}

\subsection{Measurement of Penetration Depth}

The optical microscopic analysis of CF melts flow part into hematite substrate heated at $1300^{\circ} \mathrm{C}$ for $10 \mathrm{~min}$ are shown in Fig. 2((a) with $5 \%$ porosity and (b) with $15 \%$ porosity). It was found that the CF slag tablet was melted and spread, and penetrated into hematite substrate. Moreover, it was clearly found that the penetration depth into hematite substrate with $15 \%$ porosity was far deeper than that of hematite substrate with $5 \%$ porosity. The penetration depth of melts into a hematite substrate of each sample was measured as an interval from the initial interface to the deepest flow position of melts into substrate from the re- sults of optical microscopic analysis shown by arrows in Fig. 2.

Figures 3 and $\mathbf{4}$ show the relationship between the heating period and the penetration depth of $\mathrm{CF}$ and $\mathrm{CF}$ with $\mathrm{Al}_{2} \mathrm{O}_{3}$ or $\mathrm{SiO}_{2}$ melts into hematite substrate with $5 \%$ porosity and that with $15 \%$ porosity, respectively. From these figures, it was clear that the penetration depth of hematite sinter with $15 \%$ porosity was 10 times deeper than that with $5 \%$ porosity. Figure 3 shows that the penetration depth of $\mathrm{CF}$ melts into hematite substrate with $5 \%$ porosity was decreased by the addition of $\mathrm{Al}_{2} \mathrm{O}_{3}$ or $\mathrm{SiO}_{2}$. Furthermore, the addition of $\mathrm{SiO}_{2}$ was more effective than the addition of $\mathrm{Al}_{2} \mathrm{O}_{3}$ for decreasing the penetration depth of $\mathrm{CF}$ melts $(\mathrm{CF}>\mathrm{CF}-3 \mathrm{~A} \approx \mathrm{CF}-5 \mathrm{~A}>\mathrm{CF}-3 \mathrm{~S}>\mathrm{CF}-5 \mathrm{~S})$. On the other hand, Fig. 4 shows that the penetration depth of CF melts into hematite substrate with $15 \%$ porosity was found almost in reverse order with comparison to that with $5 \%$ porosity, in which the penetration depth of $\mathrm{CF}$ melts was increased by the addition of $\mathrm{SiO}_{2}$ and that with the addition of $\mathrm{Al}_{2} \mathrm{O}_{3}$ was similar to that of $\mathrm{CF}$ melts $(\mathrm{CF}<\mathrm{CF}-5 \mathrm{~A}<\mathrm{CF}-3 \mathrm{~A} \approx \mathrm{CF}$ $5 \mathrm{~S}<\mathrm{CF}-3 \mathrm{~S}$ ).

\subsection{Evaluation of Penetration Behavior of Slag Melts into Hematite Substrate}

Figure 5(a) to 5(c) shows the EPMA mapping of $\mathrm{Fe}, \mathrm{Ca}$, $\mathrm{Al}$ and $\mathrm{Si}$ at the interface region of CF, CF-5A and CF-5S melts to the hematite substrate with $5 \%$ porosity after heated at $1300^{\circ} \mathrm{C}$ for $10 \mathrm{~min}$, respectively. Other melts, CF$3 \mathrm{~A}$ and $\mathrm{CF}-3 \mathrm{~S}$, showed similar behavior at the interface region. Note that these melts did not penetrate preferentially along or into grain boundaries of hematite substrate. In the case of CF-5A melts, as shown in Fig. 5(b), the reaction layer containing $\mathrm{Al}_{2} \mathrm{O}_{3}$ was present at the vicinity of the interface. According to the $\mathrm{Fe}_{2} \mathrm{O}_{3}-\mathrm{CaO}-\mathrm{Al}_{2} \mathrm{O}_{3}$ ternary phase diagram, ${ }^{10-12)}$ this reaction layer were solid solutions of ternary calcium ferrite $\left(\mathrm{CaO} \cdot 3\left(\mathrm{Fe}_{x} \mathrm{Al}_{1-x}\right)_{2} \mathrm{O}_{3}\right.$ system) formed of $\mathrm{CaO} \cdot 3 \mathrm{Al}_{2} \mathrm{O}_{3}$ and $\mathrm{CaO} \cdot 3 \mathrm{Fe}_{2} \mathrm{O}_{3}$. These results identified that the penetration of melts into hematite substrate along grain boundaries did not take place in the case of $5 \%$ porosity, and melts/hematite interface moved down by dissolution of solid hematite into CF melts. It, therefore, suggested that the penetration depth was controlled by the solubility gap of $\mathrm{Fe}_{2} \mathrm{O}_{3}$ for CF-based melts, $\Delta \mathrm{Fe}_{2} \mathrm{O}_{3}$ (mol\%), which is the difference of the $\mathrm{Fe}_{2} \mathrm{O}_{3}$ concentration between the initial value and the saturation one that were determined by the $\mathrm{Fe}_{2} \mathrm{O}_{3}-\mathrm{CaO},{ }^{14)} \mathrm{Fe}_{2} \mathrm{O}_{3}-\mathrm{CaO}-\mathrm{Al}_{2} \mathrm{O}_{3}{ }^{10-12)}$ and $\mathrm{Fe}_{2} \mathrm{O}_{3}-$ $\mathrm{CaO}-\mathrm{SiO}_{2}{ }^{13)}$ phase diagrams.

Figures 6 and 7 show the relationship between the penetration depth and $\Delta \mathrm{Fe}_{2} \mathrm{O}_{3}(\mathrm{~mol} \%)$ for the samples heated at $1300^{\circ} \mathrm{C}$ for $5 \mathrm{~min}$ and for $10 \mathrm{~min}$, respectively. The penetration depth of all CF-based melts into hematite substrate with $5 \%$ porosity was monotonically increased with $\Delta \mathrm{Fe}_{2} \mathrm{O}_{3}$ (mol\%), so that $\Delta \mathrm{Fe}_{2} \mathrm{O}_{3}$ (mol\%) could be considered as the driving force of the dissolution of hematite into CF-based melts.

In the case of hematite substrate with $15 \%$ porosity, CFbased melts penetrated into hematite substrate along grain boundaries, and the penetration depth was 10 times deeper than the case of hematite substrate with $5 \%$ porosity for each slag.

Figures 9, 10 and 11 show the results of EPMA analyses 

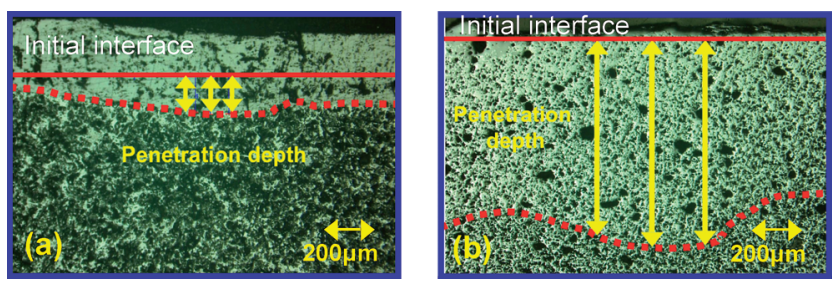

Fig. 2. Optical microscopic analysis of slag melt flow part (porosity of hematite substrate; $(a)=5 \%,(b)=15 \%$ ).

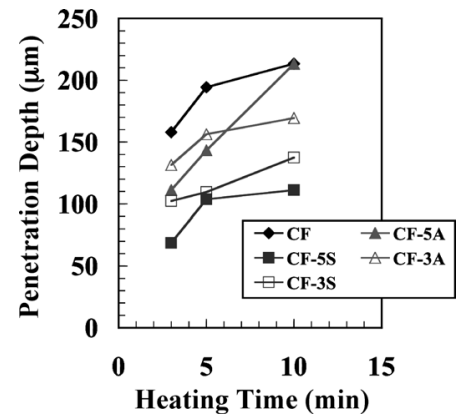

Fig. 3. Relationship between heating time and penetration depth (porosity $=5 \%$ ).

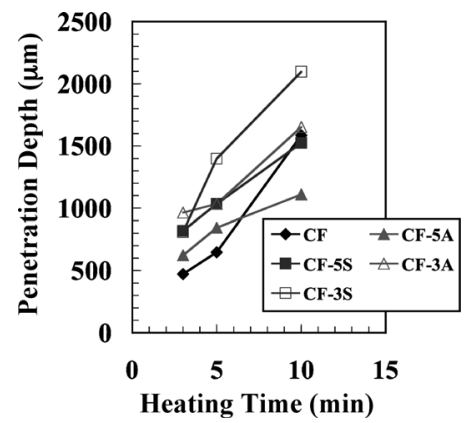

Fig. 4. Relationship between heating time and penetration depth (porosity $=15 \%$ ).
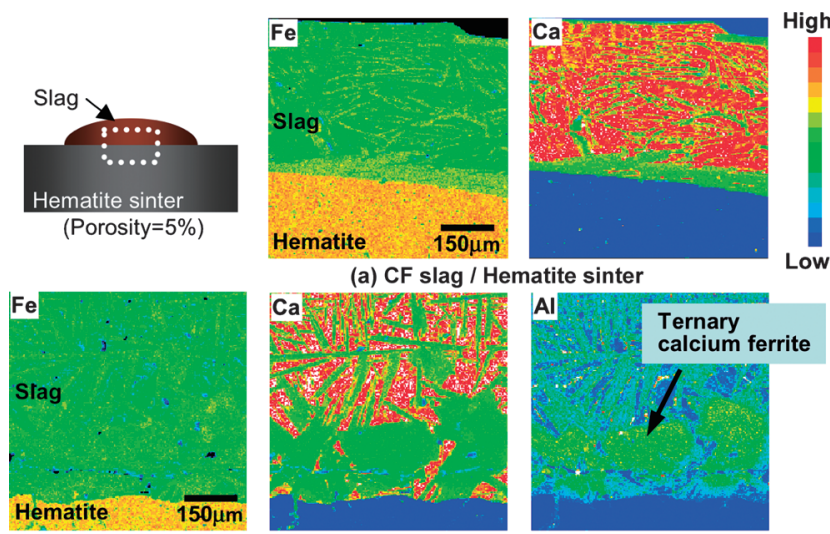

(a) CF slag / Hematite sinte
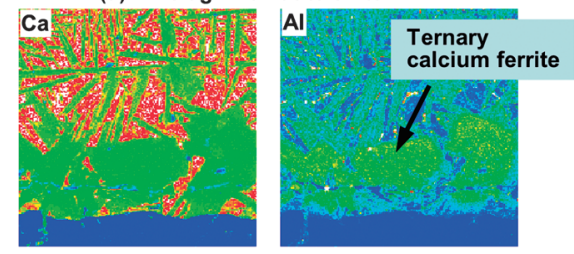

(b) $\mathrm{CF}-5 \% \mathrm{Al}_{2} \mathrm{O}_{3}$ slag / Hematite sinter

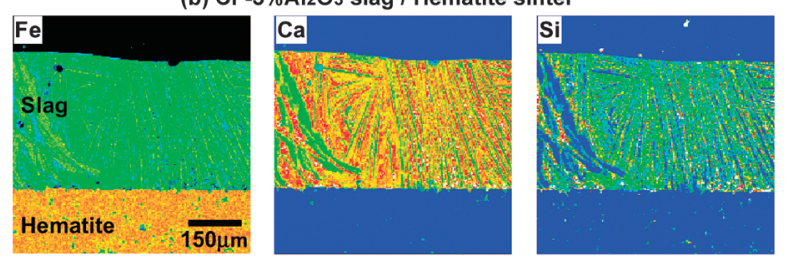

(c) $\mathrm{CF}-5 \% \mathrm{SiO}_{2}$ slag / Hematite sinter

Fig. 5. Mapping analysis of interface between slag and hematite substrate with porosity of $5 \%$ heated at $1300^{\circ} \mathrm{C}$ for $10 \mathrm{~min}$.

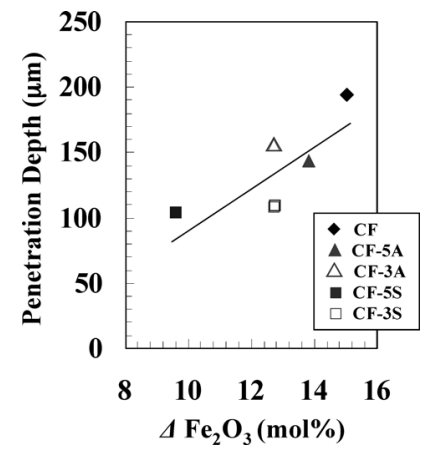

Fig. 6. Relationship between solubility gap, $\Delta \mathrm{Fe}_{2} \mathrm{O}_{3}$, and penetration depth heated at $1300^{\circ} \mathrm{C}$ for $5 \mathrm{~min}$ (porosity $=5 \%$ ).

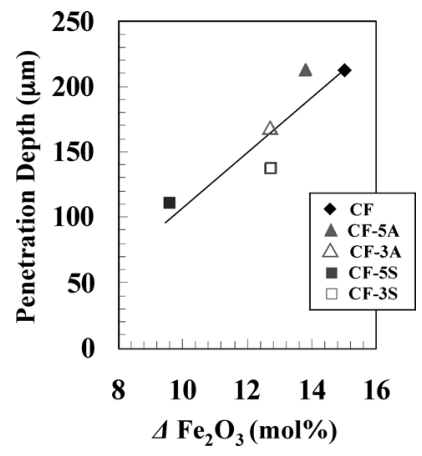

Fig. 7. Relationship between solubility gap, $\Delta \mathrm{Fe}_{2} \mathrm{O}_{3}$, and penetration depth heated at $1300^{\circ} \mathrm{C}$ for $10 \mathrm{~min}$ (porosity $=5 \%$ ).

at the different depth (A) to (C) as shown in Fig. 8 of $\mathrm{CF}$, CF-5A and CF-5S melts to the hematite substrate with $15 \%$ porosity after heated at $1300^{\circ} \mathrm{C}$ for $5 \mathrm{~min}$. Other melts, CF-3A and CF-3S, showed similar penetration behavior into hematite substrate. The chemical compositions of slag pointed by (1)-(4) in Figs. 9, 10 and 11 are shown in Tables 2, 3 and 4. As shown in these figures, the penetration depth of slag melts into hematite sinter along grain boundaries was clearly seen for each type of melts for the hematite substrate with $15 \%$ porosity. In the case of CF-5A slag with $15 \%$ porosity shown in Fig. 10 , the reaction layer containing $\mathrm{Al}_{2} \mathrm{O}_{3}$, namely ternary calcium ferrite $(\mathrm{CaO} \cdot 3$ $\left(\mathrm{Fe}_{x} \mathrm{Al}_{1-x}\right)_{2} \mathrm{O}_{3}$ system), was present at the vicinity of the interface, as in the case of Fig. 5(b), and CF melts without $\mathrm{Al}_{2} \mathrm{O}_{3}$ penetrated into hematite substrate. It was found from Tables 2 and 3 that the concentration of $\mathrm{Fe}_{2} \mathrm{O}_{3}$ was increased with increasing the penetration depth in the case of $\mathrm{CF}$ and CF-5A slag. Consequently, it is predicted from the phase diagrams, ${ }^{14}$ ) that the $\mathrm{Fe}_{2} \mathrm{O}_{3}$-saturated liquid phase with solid phase penetrated into hematite substrate in the case of CF and CF-5A slag. On the other hand, it was seen from Fig. 11, Table 4 and the phase diagrams ${ }^{13)}$ that the liquid along with $\mathrm{SiO}_{2}$ penetrated into hematite substrate which did not saturated with any solid phase in the case of CF-5S slag.

The penetration depth of liquid phase into substrate can be correlated with the surface tension of melts and inversely proportional to the viscosity. ${ }^{15)}$ It has been reported that the square value of the penetration depth of glass melts into alumina substrate was proportional to the ratio between the surface tension and the viscosity of glass melts, $\gamma / \eta{ }^{16)}$ 
Consequently, the penetration depth of CF-based slag melts into hematite sinter with $15 \%$ porosity was correlated from the viewpoints of the relation to the viscosity and the surface tension of melts, namely the value of $\gamma / \eta$.

The viscosity of suspension liquid for $\mathrm{CF}$ and $\mathrm{CF}$ with $\mathrm{Al}_{2} \mathrm{O}_{3}$, namely of liquid phase with solid, was calculated by the Eq. (1). ${ }^{17,18)}$

$$
\eta_{\mathrm{r}}=\frac{\eta}{\eta_{0}}
$$

where $\eta_{\mathrm{r}}, \eta$ and $\eta_{0}$ are the viscosity of relative value, of suspension and of liquid phase (disperse phase). The values

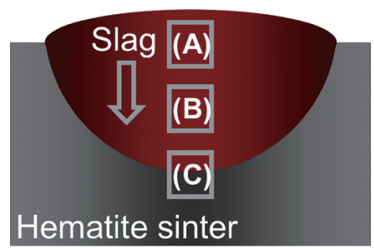

(Porosity=15\%)

Fig. 8. Schematic illustration of mapping analysis points in samples.
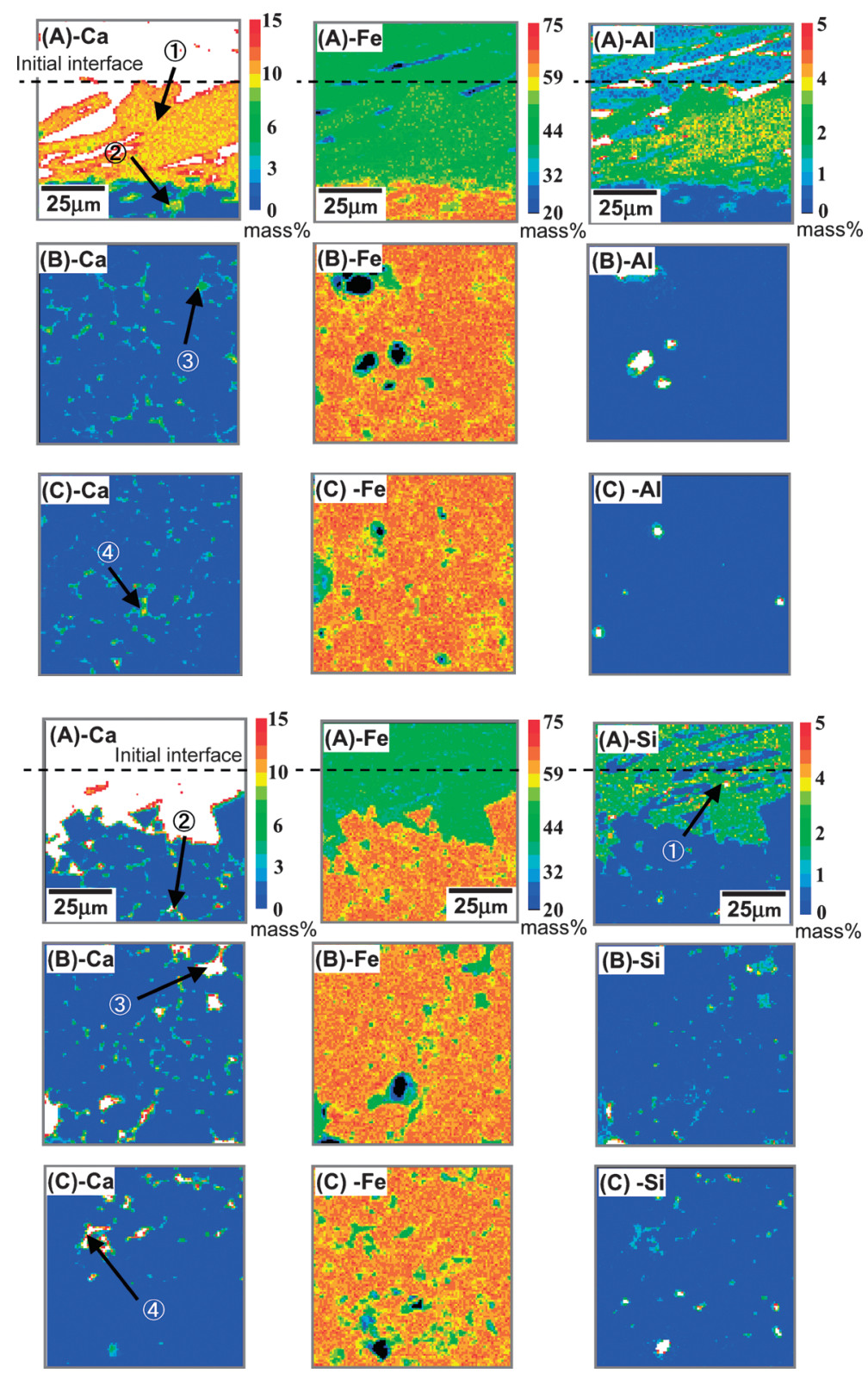
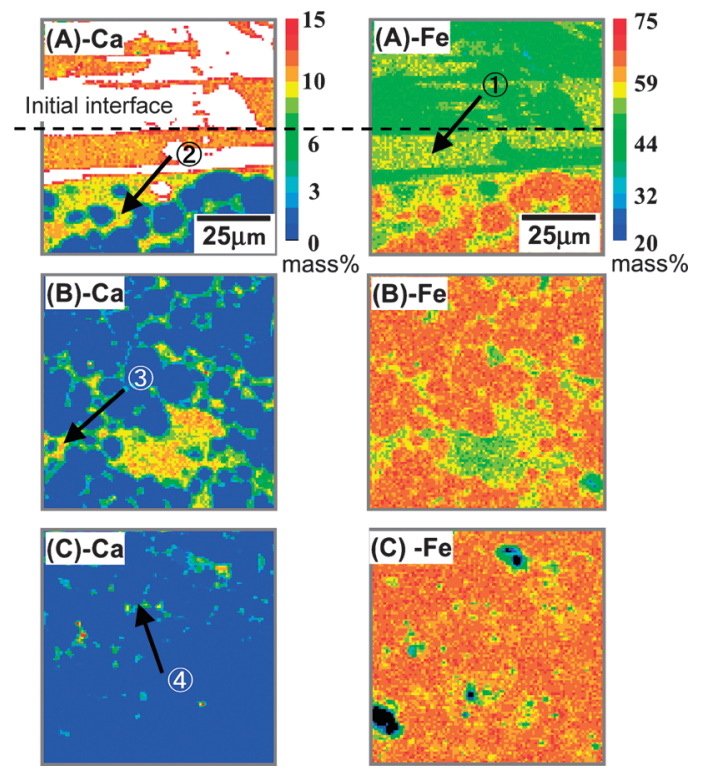

Fig. 9. Mapping analysis of interface and penetration layer between CF slag and hematite substrate with porosity of $15 \%$ heated at $1300^{\circ} \mathrm{C}$ for $5 \mathrm{~min}$. ((A), (B), (C) correspond to analysis points in sample shown in Fig. 8.)

Fig. 10. Mapping analysis of interface and penetration layer between $\mathrm{CF}-5 \mathrm{Al}_{2} \mathrm{O}_{3}$ slag and hematite substrate with porosity of $15 \%$ heated at $1300^{\circ} \mathrm{C}$ for $5 \mathrm{~min}$. ((A), (B), (C) correspond to analysis points in sample shown in Fig. 8.)
Fig. 11. Mapping analysis of interface and penetration layer between $\mathrm{CF}-5 \mathrm{SiO}_{2}$ slag and hematite substrate with porosity of $15 \%$ heated at $1300^{\circ} \mathrm{C}$ for $5 \mathrm{~min}$. ((A), (B), (C) correspond to analysis points in sample shown in Fig. 8.) 
Table 2. Chemical compositions of melts pointed by (1)-(4) in Fig. 9 (mass \%).

\begin{tabular}{l|l}
\hline$(1)$ & $17 \mathrm{CaO} \cdot 83 \mathrm{Fe}_{2} \mathrm{O}_{3}$ \\
\hline$(2)$ & $15 \mathrm{CaO} \cdot 85 \mathrm{Fe}_{2} \mathrm{O}_{3}$ \\
\hline$(3)$ & $14 \mathrm{CaO} \cdot 86 \mathrm{Fe}_{2} \mathrm{O}_{3}$ \\
\hline$(4)$ & $11 \mathrm{CaO} \cdot 89 \mathrm{Fe}_{2} \mathrm{O}_{3}$ \\
\hline
\end{tabular}

Table 3. Chemical compositions of melts pointed by (1)-(4) in Fig. $10(\operatorname{mass} \%)$

\begin{tabular}{c|c}
\hline$(1)$ & $16 \mathrm{CaO} \cdot 78 \mathrm{Fe}_{2} \mathrm{O}_{3} \cdot 6 \mathrm{Al}_{2} \mathrm{O}_{3}$ \\
\hline$(2)$ & $16 \mathrm{CaO} \cdot 83 \mathrm{Fe}_{2} \mathrm{O}_{3} \cdot 1 \mathrm{Al}_{2} \mathrm{O}_{3}$ \\
\hline$(3)$ & $13 \mathrm{CaO} \cdot 87 \mathrm{Fe}_{2} \mathrm{O}_{3}$ \\
\hline$(4)$ & $12 \mathrm{CaO} \cdot 88 \mathrm{Fe}_{2} \mathrm{O}_{3}$ \\
\hline
\end{tabular}

Table 4. Chemical compositions of melts pointed by (1)-(4) in Fig. 11 (mass\%).

\begin{tabular}{c|c}
\hline$(1)$ & $16 \mathrm{CaO} \cdot 84 \mathrm{Fe}_{2} \mathrm{O}_{3}$ \\
\hline$(2)$ & $23 \mathrm{CaO} \cdot 72 \mathrm{Fe}_{2} \mathrm{O}_{3} \cdot 5 \mathrm{SiO}_{2}$ \\
\hline$(3)$ & $24 \mathrm{CaO} \cdot 72 \mathrm{Fe}_{2} \mathrm{O}_{3} \cdot 4 \mathrm{SiO}_{2}$ \\
\hline$(4)$ & $23 \mathrm{CaO} \cdot 74 \mathrm{Fe}_{2} \mathrm{O}_{3} \cdot 3 \mathrm{SiO}_{2}$ \\
\hline
\end{tabular}

of viscosity of liquid phase $\left(\eta_{0}\right)$ were obtained by extrapolating the temperature dependence of the viscosity measured previously ${ }^{19,20)}$ to the temperature of $1300^{\circ} \mathrm{C}$. The values of viscosity of relative value $\left(\eta_{\mathrm{r}}\right)$ were calculated by the Eq. (2) of Einstein-Roscoe. ${ }^{17,18)}$

$$
\eta_{\mathrm{r}}=(1-a \phi)^{-n}
$$

where $a$ and $n$ are constant, and $\phi$ is a volume fraction of solid in liquid phase. The values of $a=1.35$ and $n=2.5$ given for spherical solid particles ${ }^{17,18)}$ were used in this study. The values of $\phi$ were calculated based on the phase diagrams, ${ }^{10-14)}$ and the chemical compositions of the deepest position of the penetration layer for each melts. Moreover, the surface tension of just as liquid phase for each melts were obtained by extrapolating the temperature dependence of the surface tension measured previously ${ }^{19)}$ to the temperature of $1300^{\circ} \mathrm{C}$. In the case of $\mathrm{CF}$ with $\mathrm{SiO}_{2}$ melts, the viscosity and the surface tension were obtained by extrapolating the temperature dependence of the surface tension and that of the viscosity measured previously ${ }^{19,20)}$ for the chemical compositions of liquid phase at the deepest position of the penetration layer for each melts. Table 5 shows the values of $\gamma / \eta$ with each values of $\phi, \eta$ and $\gamma$. The viscosities of $\mathrm{CF}$ and $\mathrm{CF}$ with $\mathrm{Al}_{2} \mathrm{O}_{3}$ slag are larger than that of $\mathrm{CF}$ with $\mathrm{SiO}_{2}$ slag due to containing of solid phase. Therefore, the values of $\gamma / \eta$ for $\mathrm{CF}$ with $\mathrm{SiO}_{2}$ melts indicates one-order larger, compared with those for $\mathrm{CF}$ and CF with $\mathrm{Al}_{2} \mathrm{O}_{3}$ melts.

As shown in Fig. 12, the square values penetration depth $\left(L^{2}\right)$ was directly proportional to the value of $\gamma / \eta$, and increased with the value of $\gamma / \eta$. It suggested that the penetration behavior depth of CF-based melts into hematite substrate with $15 \%$ porosity was controlled by capillary force, represented as the ratio between the surface tension and the viscosity of melts.
Table 5. Volume fraction of solid $\phi$, viscosity $\eta$, surface tension $\gamma$ and the value of $\gamma / \eta$ of melts.

\begin{tabular}{c|c|c|c|c}
\hline & $\phi$ & $\eta(\mathrm{Pa} \cdot \mathrm{s})$ & $\gamma(\mathrm{mN} / \mathrm{m})$ & $\gamma / \eta$ \\
\hline CF & 0.353 & 0.115 & 677 & 2.56 \\
\hline CF-3A & 0.353 & 0.159 & 677 & 2.56 \\
\hline CF-5A & 0.294 & 0.112 & 677 & 3.61 \\
\hline CF-3S & 0 & 0.044 & 672 & 11.7 \\
\hline CF-5S & 0 & 0.053 & 671 & 11.0 \\
\hline
\end{tabular}

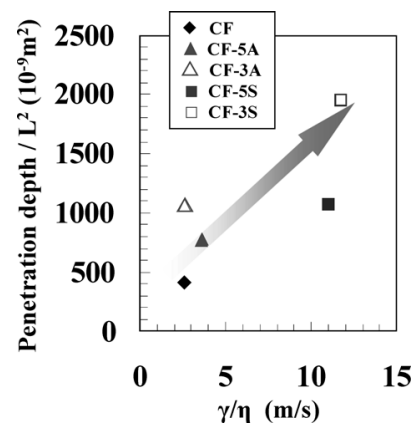

Fig. 12. Relationship between $\gamma / \eta$ and penetration depth $\left(L^{2}\right)$ heated at $1300^{\circ} \mathrm{C}$ for $5 \mathrm{~min}$ (porosity $=15 \%$ ).

\section{Conclusions}

Effects of adding $\mathrm{SiO}_{2}$ or $\mathrm{Al}_{2} \mathrm{O}_{3}$ on the penetration characteristics of calcium ferrite (CF) melts into hematite sinter with the different percentage of porosity were examined, and were discussed from the viewpoints of the relation to the solubility gap, $\Delta \mathrm{Fe}_{2} \mathrm{O}_{3}(\mathrm{~mol} \%)$, viscosity and surface tension of the CF-based melts. The results obtained are as follows:

(1) The penetration depth of CF melts into dense hematite substrate with $5 \%$ porosity was depressed by the addition of $\mathrm{SiO}_{2}$ or $\mathrm{Al}_{2} \mathrm{O}_{3}$, and the addition of $\mathrm{SiO}_{2}$ was more effective than that of $\mathrm{Al}_{2} \mathrm{O}_{3}$.

(2) The penetration of CF-based melts along grain boundaries into dense hematite substrate with $5 \%$ porosity did not take place, and melts/hematite interface moved down by dissolution of solid hematite into these melts.

(3) The penetration depth of CF-based melts into dense hematite substrate with $5 \%$ porosity was mostly determined by $\Delta \mathrm{Fe}_{2} \mathrm{O}_{3}(\mathrm{~mol} \%)$, which meant that the dissolution of hematite into CF-based melts was rate-determine.

(4) The penetration depth of CF melts into porous hematite substrate with $15 \%$ porosity was accelerated by the addition of $\mathrm{SiO}_{2}$ because of reducing the melting temperature in calcium ferrite system. The penetration depth of CF melts with $\mathrm{Al}_{2} \mathrm{O}_{3}$ was almost the same as that of $\mathrm{CF}$ melts. These melts penetrated into hematite substrate with crystallization due to the increase of the melting temperature in calcium ferrite system by the dissolution of hematite into the melts.

(5) The penetration of CF-based melts along grain boundaries into porous hematite substrate with $15 \%$ porosity occurred, and the penetration depth was 10 times deeper than the case of dense hematite substrate with $5 \%$ porosity for each slag.

(6) The penetration depth of CF-based melts into hematite substrate with $15 \%$ porosity was dominated by the ratio between the surface tension and viscosity of melts tak- 
ing the suspension-corrected into consideration.

\section{Acknowledgements}

We thank Dr. Kenji Kaneko of Department of Materials Science and Engineering, Graduate School of Engineering, Kyushu University for his valuable discussions.

\section{REFERENCES}

1) H. Matsumura, K. Morioka, M. Shimizu, S. Noda and T. Matsuo: Tetsu-to-Hagané, 82 (1996), 23.

2) Y. Hida, J. Okazaki, K. Nakamura, K. Uekawa and N. Kasai: Tetsuto-Hagané, 78 (1993), 23.

3) J. Okazaki, K. Higuchi and Y. Hosotani: CAMP-ISIJ, 13 (2000), 800.

4) Y. Hida, J. Okazaki, K. Ito and M. Sasaki: Tetsu-to-Hagané, 73 (1987), 1893

5) B. Phillips and A. Muan: J. Am. Ceram. Soc., 41 (1958), 445.

6) T. Inazumi and M. Koyama: 165th Nishiyama Memorial Seminar, ISIJ, Tokyo, (1997), 25.

7) Y. Hida and Y. Nosaka: Tetsu-to-Hagané, 78 (1992), 960.
8) T. Maeda, K. Nishioka, K. Nakashima and M. Shimizu: ISIJ Int., 44 (2004), 2046

9) K. Nakashima, N. Saito, S. Shinozaki, R. Tanaka, T. Maeda, M. Shimizu and K. Mori: ISIJ Int., 44 (2004), 2052.

10) D. H. Lister and F. P. Glasser: Trans. Br. Ceram. Soc., 66 (1967), 293.

11) S. Watanabe, T. Maeda and Y. Ono: CAMP-ISIJ, 7 (1994), 1025.

12) S. Watanabe, T. Maeda and Y. Ono: CAMP-ISIJ, 8 (1995), 1087.

13) B. Phillips and A. Muan: J. Am. Ceram. Soc., 42(1959), 413.

14) B. Phillips and A. Muan: J. Am. Ceram. Soc., 41 (1958), 448, 449.

15) R. M. German: Liquid Phase Sintering, Plenum Publishing, New York, (1985), 91

16) K. Morinaga, H. Takebe and Y. Kuromitsu: Ceramic Microstructures, Plenum Press, New York and London, (1998), 543.

17) T. Iida, Y. Kita, M. Ueda, K. Mori and K. Nakashima: Viscosity of Molten Slag and Glass, Published by Agune-Gijyutsu-Center, Japan, (2003), 105.

18) S. Yagi and T. Ototake: Kogyo-Kagaku-Zasshi, 61 (1958), 1404.

19) N. Saitou, N. Hori, K. Nakashima and K. Mori: Metall. Mater. Trans. $B, 34 \mathrm{~B}$ (2003), 509.

20) Master Thesis (Kyushu University); unpublished research (2008). 